\title{
Assessing the relative role of climate on litterfall in Mediterranean cork oak forests
}

\author{
Enrique Andivia (1), \\ Jordi Bou ${ }^{(2)}$, \\ Manuel Fernández ${ }^{(3)}$, \\ Antonia Caritat ${ }^{(2)}$, \\ Reyes Alejano ${ }^{(3)}$, \\ Lluís Vilar ${ }^{(2)}$, \\ Javier Vázquez-Piqué ${ }^{(3)}$
}

\begin{abstract}
Litterfall plays a key role in the dynamic of forest ecosystems, ultimately determining forest productivity and carbon and nutrient cycling. Increasing our understanding on the role of structural and environmental factors controlling litterfall amount and seasonality is of paramount importance for modelling and estimating soil carbon sequestration and nutrient cycling under climate change scenarios. However, the effect of climatic conditions on litterfall has been scarcely studied, especially in Mediterranean ecosystems. Here, we used nine years of seasonally collected litterfall data in two contrasting Mediterranean cork oak forests to evaluate the effect of climatic variables on leaf fall and litterfall. First, we isolated the litterfall seasonal trend and the between-sites differences in production by using linear mixed models. Then, we evaluated the effect of climatic variables and whether this effect was site-specific. We found a consistent litterfall seasonal pattern, mainly determined by leaf shedding (70\% of litterfall). Leaf fall mainly occurs in spring with a second but much smaller peak in autumn some years. Mean temperature, precipitation and mean wind speed strongly influenced litterfall, but this effect was sitespecific. In the forest site located at higher latitude and altitude, leaf fall increased linearly with temperature and showed a positive quadratic response to precipitation. In the water-limited site, leaf fall was reduced as temperature increased and did not respond to precipitation. These results have implications for modelling and predicting soil carbon sequestration, nutrient cycling, and the forest ecosystem productivity. Specifically, carbon and nutrient cycling models can be improved by incorporating idiosyncratic forest sites responses to climatic variability.
\end{abstract}

Keywords: Climate, Leaf Fall, Litterfall, Modelling, Plant-soil Interactions, Quercus suber, Seasonality

\begin{abstract}
Introduction
In forest ecosystems, litterfall is the largest source of aboveground organic material input to soil (Berg \& Laskowski 2005). It constitutes a key process in the dynamic of forest ecosystems determining the transfer of energy and nutrients (Roig et al. 2005, Hobbie 2015). As nutrient availability ultimately influences primary production, the amount, seasonality and the rate of decomposition of litterfall have profound ef fects on the productivity and the energy flow of forest ecosystems (DeForest et al.

2009, Chen et al. 2017). Besides maintaining soil fertility, litterfall plays other important roles in forest ecosystems, such as buffering changes in soil water content and temperature, reducing erosion, and increasing biodiversity (Sayer 2005). Soil respiration and soil organic content are also indirectly regulated by litterfall (Han et al. 2015). Therefore, litterfall is of paramount importance for modelling and estimating soil carbon sequestration and nutrient cycling in forest ecosystems (Pedersen \& Bille-Hansen 1999, Liski et al. 2005). In this
\end{abstract}

(1) Departamento de Biodiversidad, Ecología y Evolución, Universidad Complutense de Madrid (Spain); (2) LAGP-Flora i Vegetació, Institut de Medi Ambient, Universitat de Girona (Spain); (3) Departamento de Ciencias Agroforestales, Escuela Técnica Superior de Ingeniería, Universidad de Huelva (Spain)

@ Enrique Andivia (e.andivia@gmail.com)

Received: Apr 24, 2018 - Accepted: Oct 15, 2018

Citation: Andivia E, Bou J, Fernández M, Caritat A, Alejano R, Vilar L, Vázquez-Piqué J (2018). Assessing the relative role of climate on litterfall in Mediterranean cork oak forests. iForest 11: 786-793. - doi: 10.3832/ifor2825-011 [online 2018-12-14]

Communicated by: Andrea Cutini context, increasing our understanding of the role of structural and environmental factors on controlling litterfall amount and seasonality would help to improve models predictions (Liski et al. 2005), but also to guide forest management.

The amount of litterfall is related to environmental and structural properties, such as stand age, basal area, or canopy cover (Berg \& Laskowski 2005, Roig et al. 2005). Nonetheless, several studies point to the pivotal role of climatic variables, such as temperature, radiation, or storms on litterfall amount and seasonality (Caritat et al. 2006, Andivia et al. 2013, Zhang et al. 2014, Bou et al. 2015, Liu et al. 2015). Litterfall is influenced by phenology, evapotranspiration and photosynthesis (Oliveira et al. 1996, Berg \& Laskowski 2005, Zhang et al. 2014). These mechanisms are ultimately affected by climatic conditions. Thus, climate change may have significant effects on litterfall. For example, climate warming is causing serious phenological changes in plants (Estiarte \& Peñuelas 2014) that might induce changes in litterfall seasonality affecting soil fertility and the net primary production of forest ecosystems. A mechanistic understanding of the relationship between climatic conditions and litter- 
fall is essential to accurately predict forest ecosystem productivity under climate change scenarios. This is especially true for those ecosystems in which water and nutrients are limiting.

The Mediterranean region has been identified as a primary hotspot particularly vulnerable to the impacts of climate change (Giorgi 2006). Scenarios for climate change predict increasing temperatures and decreasing precipitation for this area (Christensen \& Christensen 2007). The productivity of evergreen Mediterranean ecosystems depends on intra- and inter-annual climatic fluctuations (Falge et al. 2002). The impact of environmental stress on plant growth has inspired a vast amount of publications, however the effect of environmental conditions on litterfall has been scarcely studied (Pausas 1997). Most of this research has been focused on reporting litterfall seasonality and nutrient return to the soil (Bellot et al. 1992, Rapp et al. 1999, Bussotti et al. 2003, Andivia et al. 2010). In addition, studies aimed at disentangling the role of climate on litterfall reported contradictory results. Liu et al. (2015) showed an increase in litterfall of Mediterranean tree species with decreasing precipitation in a rainfall-manipulation experiment, whereas Caritat et al. (2006) and Andivia et al. (2013) reported a positive relationship between precipitation and litterfall in Mediterranean evergreen oaks. Evaluating the relationship between litterfall and climatic conditions is challenging because of the large spatial, inter-annual and seasonal variability of both, litterfall and climatic conditions. Indeed, some studies have suggested that this evaluation should be addressed using within-site sampling (Metcalfe et al. 2014). In addition, the attribution of litterfall trends to climatic vari- ability is troublesome, and the effect of climate should be assessed after isolating the seasonality of litterfall patterns.

Cork oak is a sclerophyllous evergreen oak and one of the most important forest tree species of the Mediterranean basin. Cork oak woodlands support high levels of biodiversity and ecosystem services, and they represent a model of sustainable ecosystem management with co-existing human activities, such as cork extraction and natural resource conservation. This has led to its inclusion in the Annex I of the European Union Habitats Directive (92/43/CEE). In this study, we used nine years of seasonally collected litterfall data in two contrasting cork oak (Quercus suber L.) forests to evaluate the effect of climatic variables on litterfall and leaf fall. By using a combination of linear mixed models we first isolated the seasonal pattern of litterfall, and the idiosyncratic site effect attributable to between-sites differences in forest structure and litterfall production. Then, we evaluated the effect of climatic variables and whether this effect was site-specific.

\section{Materials and methods}

\section{Study sites}

The study sites were located in two contrasting forest areas, Hinojos and Montseny. These differ mainly in forest structure (tree density and basal area) and climate (Fig. 1) as a consequence of different management regimes, and its geographical distance. Thus, Hinojos is a dehesa system in the south of Spain, while Montseny is a natural forest in the north of the Mediterranean biome. The main use of both forests is cork extraction.

The Montseny site is located in a Mediterranean cork oak forest in northeastern

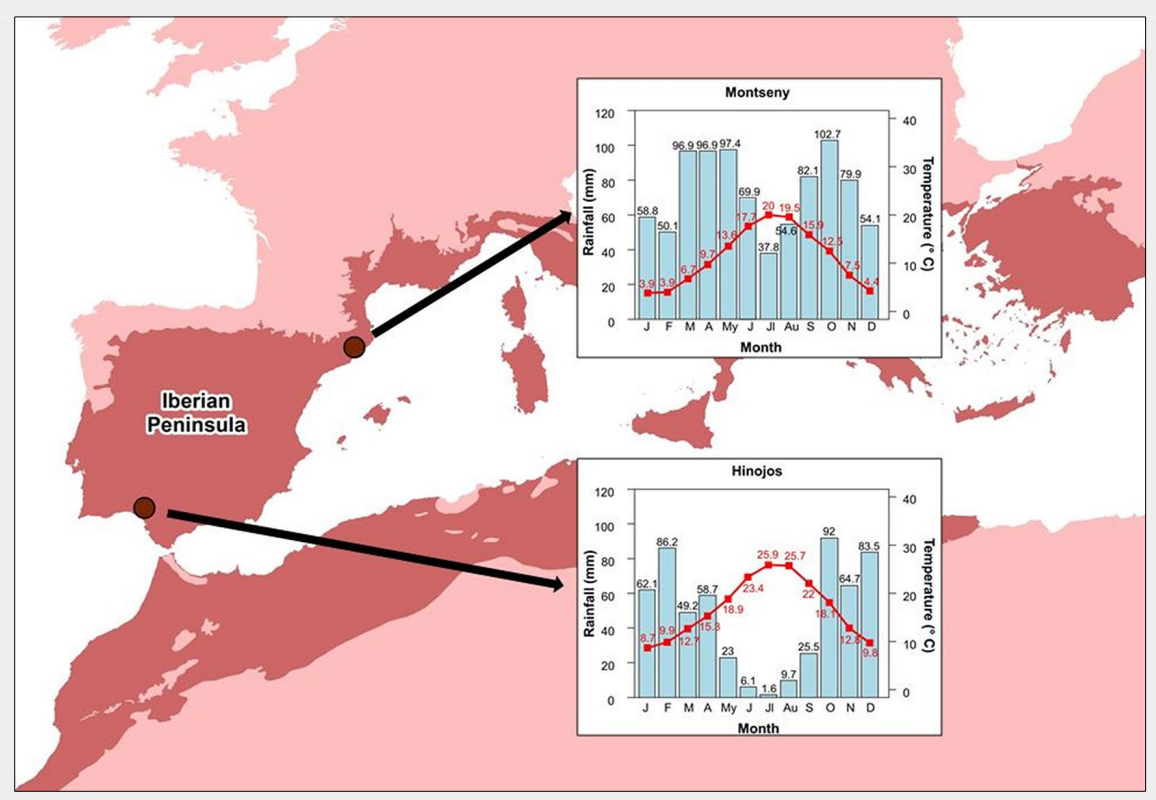

Fig. 1 - Locations of the study sites (Hinojos and Montseny) in the Iberian Peninsula and their climate diagram during the study period. The Mediterranean ecoregion is depicted in dark red.
Spain (Barcelona, Catalonia), in a flat area with an altitude of $780 \mathrm{~m}$ a.s.l. $\left(41^{\circ} 44^{\prime} \mathrm{N}\right.$, $02^{\circ} 23^{\prime} \mathrm{W}$ ) and with a tree density of 1082 trees $\mathrm{ha}^{-1}$. Cork oak is the dominant tree species, with a density of 700 trees ha ${ }^{-1}$ and a basal area of $49.5 \mathrm{~m}^{2} \mathrm{ha}^{-1}$, while holm oak (Quercus ilex $L$ subsp. ilex) appears as secondary tree species (382 trees ha ${ }^{-1}$ and 3.2 $\left.\mathrm{m}^{2} \mathrm{ha}^{-1}\right)$. The understory community is mainly composed of Arbutus unedo L., Crataegus monogyna Jacp., Erica arborea L. and Cistus salviifolius L. The climate is Mediterranean subhumid with a mean annual precipitation of $895 \mathrm{~mm}$, a mean annual temperature of $11.3{ }^{\circ} \mathrm{C}$, a summer drought period of two months, and little interannual variability in temperature and precipitation (data from Viladrau weather station located $12 \mathrm{~km}$ away from the study plot - Fig. 1). The soil is classified as Eutric Leptosol (IUSS/WRB 2007), a stony and acidic soil with formation of a cambic horizon with moderate illuviation.

The Hinojos site is located in a Mediterranean cork oak woodland in southwestern Spain (Huelva, Andalusia), in a flat area with an altitude of $100 \mathrm{~m}$ a.s.l. $\left(37^{\circ} 19^{\prime} \mathrm{N}\right.$, $06^{\circ} 25^{\prime} \mathrm{W}$ ) and with a tree density of 100 trees ha ${ }^{-1}$. Cork oak is the dominant tree species, with a density of 84 trees ha ${ }^{-1}$ and a basal area of $7.2 \mathrm{~m}^{2}$ ha-1, while holm oak appears as secondary tree species (16 trees ha ${ }^{-1}$ and $0.9 \mathrm{~m}^{2}$ ha-1). The understory community is mainly composed of Pistacia lentiscus L., Daphne gnidium L., Chamaerops humilis L., Halimium halimifolium L., and Cistus spp. The climate is typical Mediterranean with a mean annual precipitation of $579 \mathrm{~mm}$, a mean annual temperature of $18.9{ }^{\circ} \mathrm{C}$, a summer drought period of five months, and high interannual variability in temperature and precipitation (data from Pilas "Medina Garvey" weather station located $11 \mathrm{~km}$ away from the study plot - Fig. 1). The soil is classified as Haplic Regosol over a Stagnic Regosol (IUSS/WRB 2007).

\section{Litterfall sampling}

Litterfall was collected using the trapping method (Rapp et al. 1999, Caritat et al. 2006, Andivia et al. 2010) at 6 and 12 sampling points in Montseny and Hinojos, respectively. In Montseny, the six $0.25 \mathrm{~m}^{2}$ circular traps were randomly placed in a 0.04 ha plot. Because Montseny site is located in a dense forest (1082 trees ha ${ }^{-1}$ ) sampling points were all beneath tree canopies. The diameter at breast height (DBH) of cork oaks in the site ranged between 7 and 19 $\mathrm{cm}$. In Hinojos sampling points were established beneath the canopy of 12 randomly selected trees in a study area of 2 ha. The DBH of the sampled trees ranged between 22 and $35 \mathrm{~cm}$ and the mean DBH was 27.7 $\mathrm{cm}$, representing the central diameter class of all trees in the plot. To avoid any effect of orientation, four $0.16 \mathrm{~m}^{2}$ circular traps were placed at each cardinal point of every sampled tree at a distance corresponding to three quarters of the crown radius measured from the stem. Litterfall samples 
were then pooled by tree.

Samples were collected monthly for three years (2004-2006), and seasonally (winter, spring, summer and autumn) for six more years (2007-2012). Once collected, litterfall samples were oven-dried at $65^{\circ} \mathrm{C}$ for $48 \mathrm{~h}$, separated into cork oak leaves, cork oak twigs, acorns (if present) and others (mainly flowers and other plant remains), and finally weighed $( \pm 0.01 \mathrm{~g})$. Litterfall and leaf fall data were expressed as $\mathrm{g} \mathrm{m}^{-2}$, by dividing the dry weight of litter collected from each sampling point by the surface area of the litter traps. Acorns were not included as a part of litterfall. For seasonal analysis, monthly samples were pooled by season in order to analyze the whole sampled period (2004-2012).

\section{Climatic variables}

Climatic covariates were obtained from an automatic weather station at each site. Air temperature, precipitation, relative humidity, PAR radiation, and wind speed were registered every 15 minutes. Climatic covariates, including mean temperature, mean minimum temperature, mean maximum temperature, mean relative humidity, minimum relative humidity, precipitation, maximum precipitation in 24 hours, mean solar PAR radiation, mean wind speed and absolute wind speed, were calculated per season for each site.

\section{Data analysis}

To analyze the seasonality of litterfall (not including acorns) and leaf fall (main litterfall fraction) we used linear mixed models (LMM). Models were fitted to log-transformed leaf fall and litterfall data in a season (9 years, from 2004 to 2012) and in a monthly basis (3 years, from 2004 to 2006), respectively. Leaf fall and litterfall data was log-transformed to achieve normality and homocedasticity. In both cases, our experimental design resulted in temporary autocorrelation due to the fact that litterfall series results in non-independency among observations within the same sampling point (i.e., repeated measurements). For these reasons, we considered each sampling point as a random term in the model. We also tested different autoregressive correlation structures for leaf fall and litterfall measurements. To do this, we adjusted models by Restricted Maximum Likelihood (REML) using different orders for the temporary autocorrelation structure and selected the one with the lowest value of the Akaike's Information Criterion adjusted for sample size (AICC).

Once the best random structure was selected, we identified the best-supported fixed effect structure by following a backward model selection procedure. First, we fitted the full model including site, year, season or month (depend on the set of data), and the interaction between them, and we compared it with a reduced model in which the triple interaction was dropt. Then, if necessary, we compared the se- lected model with models that ignored each pairwise interaction and all the main effects, respectively. If the difference in AICC between two models was $\leq 4$, then the simpler model was selected (Zuur et al. 2009). All alternative models were fitted by the Maximum Likelihood method (ML), whereas the parameters of the selected model were estimated by REML.

To analyze the effect of climatic variables on leaf fall and litterfall, we first fitted LMMs with the selected random structure (see above) but considering site and season as main fixed effect, respectively. Then, we extracted the Pearson's residuals from the selected models. These residuals are values of leaf fall and litterfall, without the effect of seasonality and site. This procedure allowed to estimate the relative effect of climatic variables avoiding likely confounding effects due to: (i) the seasonality of both, litterfall production and climatic variables; and (ii) differences in the amount of litterfall due to site characteristics. Before fitting the model, we performed a Pearson's correlation analysis for the initial set of 10 meteorological covariates (Tab. S1 in Supplementary material). In order to avoid multicollinearity, we included in the model those variables that showed a correlation coefficient $(r)$ lower than 0.6 . When two or more covariates showed $r>0.6$, we selected only one of them. Selected covariates were mean temperature $(\mathrm{mT})$, precipitation $(\mathrm{P})$ and mean wind speed (mWS). In order to account for non-linear effects, we considered these covariates in the model as second degree polynomials. To evaluate whether the effect of climatic variables was site-specific, we introduced in the model the pairwise interaction between the factor site and the selected covariates. We evaluated if the parameters of the selected model were sig-

Tab. 1 - Yearly mean amounts ( \pm standard deviation) for each litterfall fraction and location $\left(\mathrm{g} \mathrm{m}^{-2}\right)$.

\begin{tabular}{lllccl}
\hline Location & Year & Leaves & \multicolumn{1}{l}{ Twigs } & \multicolumn{1}{l}{ Others } & Total \\
\hline Hinojos & 2004 & $275.1 \pm 63.4$ & $72.9 \pm 48.4$ & $68.3 \pm 16.3$ & $416.3 \pm 71.6$ \\
& 2005 & $201.4 \pm 66.8$ & $17.3 \pm 28.5$ & $34.3 \pm 18.6$ & $252.9 \pm 83.4$ \\
& 2006 & $149.5 \pm 46.8$ & $48.1 \pm 57.3$ & $41.0 \pm 23.4$ & $238.7 \pm 93.1$ \\
& 2007 & $225.8 \pm 69.0$ & $175.3 \pm 185.8$ & $133.0 \pm 49.7$ & $534.0 \pm 113.7$ \\
& 2008 & $215.0 \pm 53.4$ & $21.2 \pm 22.0$ & $65.4 \pm 20.3$ & $301.6 \pm 85.4$ \\
& 2009 & $244.7 \pm 61.3$ & $0.1 \pm 0.2$ & $71.6 \pm 18.2$ & $316.4 \pm 105.2$ \\
& 2010 & $236.0 \pm 43.4$ & $62.1 \pm 56.0$ & $157.3 \pm 82.7$ & $455.5 \pm 71.9$ \\
& 2011 & $241.4 \pm 49.9$ & $37.4 \pm 40.1$ & $95.2 \pm 70.8$ & $374.0 \pm 90.5$ \\
& 2012 & $175.6 \pm 49.0$ & $50.9 \pm 120.5$ & $60.9 \pm 25.9$ & $287.3 \pm 88.5$ \\
\hline Montseny & 2004 & $392.0 \pm 79.5$ & $206.9 \pm 79.6$ & $79.6 \pm 20.2$ & $678.7 \pm 110.8$ \\
& 2005 & $210.2 \pm 46.1$ & $29.6 \pm 34.5$ & $41.0 \pm 35.6$ & $280.7 \pm 72.5$ \\
& 2006 & $340.7 \pm 54.5$ & $44.2 \pm 36.4$ & $72.8 \pm 24.0$ & $457.7 \pm 66.5$ \\
& 2007 & $147.5 \pm 43.8$ & $3.8 \pm 4.0$ & $23.6 \pm 12.2$ & $174.9 \pm 67.6$ \\
& 2008 & $354.0 \pm 52.8$ & $77.3 \pm 109.6$ & $43.5 \pm 6.8$ & $474.8 \pm 73.2$ \\
& 2009 & $176.3 \pm 17.2$ & $54.5 \pm 33.9$ & $28.6 \pm 12.6$ & $259.5 \pm 75.4$ \\
& 2010 & $331.6 \pm 84.5$ & $18.1 \pm 11.9$ & $104.1 \pm 51.1$ & $453.8 \pm 110.6$ \\
& 2011 & $480.0 \pm 182.3$ & $16.4 \pm 16.3$ & $63.2 \pm 22.2$ & $559.5 \pm 299.3$ \\
& 2012 & $458.8 \pm 47.0$ & $19.2 \pm 21.5$ & $46.3 \pm 11.0$ & $524.3 \pm 74.1$ \\
\hline
\end{tabular}

nificantly different from zero by a $t$-test $(p<$ 0.05 ). If the quadratic coefficient of a climatic covariate was not significant, then we simplified the model by considering only the linear term. Climatic covariates were standardized to allow comparisons across model-estimated parameters (Zuur et al. 2009). Multicollinearity was evaluated in all models using the Variance Inflation Factor (VIF > 3 indicating multicollinearity). All statistical analyses were performed in $\mathrm{R}$ ver. 3.2.5 using the package "nlme" (Pinheiro et al. 2017).

\section{Results}

\section{Litterfall amount}

Mean yearly litterfall $( \pm$ SD) for the study period was $391.1 \pm 147.2 \mathrm{~g} \mathrm{~m}^{-2}$, with overall greater production in Montseny than in $\mathrm{Hi}$ nojos $\left(429.3 \pm 183.8 \mathrm{~g} \mathrm{~m}^{-2}\right.$ and $353.0 \pm 110.5$ $\mathrm{g} \mathrm{m}^{-2}$, respectively). Litterfall was only greater in Hinojos in three out of the nine study years (2005, 2007 and 2010 - Tab. 1). Yearly litterfall for both sites were not significantly correlated $(p=0.75)$. In fact, the years of maximum and minimum amount of litterfall differ between study sites (Tab. 1). In Montseny, litterfall maximum and minimum occurred in $2004(678.7 \pm 110.8 \mathrm{~g}$ $\left.\mathrm{m}^{-2}\right)$ and $2007\left(174.9 \pm 67.6 \mathrm{~g} \mathrm{~m}^{-2}\right)$, respectively, whereas in Hinojos the greatest and lowest amount was found in 2007 (534.0 \pm $\left.113.7 \mathrm{~g} \mathrm{~m}^{-2}\right)$ and $2006\left(238.7 \pm 93.1 \mathrm{~g} \mathrm{~m}^{-2}\right)$, respectively. Leaves were the main component of litterfall accounting for $68 \%$ of the total litterfall amount followed by the fraction others (18\%) and twigs (14\%).

\section{Seasonality of litterfall and leaf fall}

The first-order autoregressive structure was selected as the random term structure for the LMMs used to analyze leaf fall and litterfall in a seasonally and monthly basis 


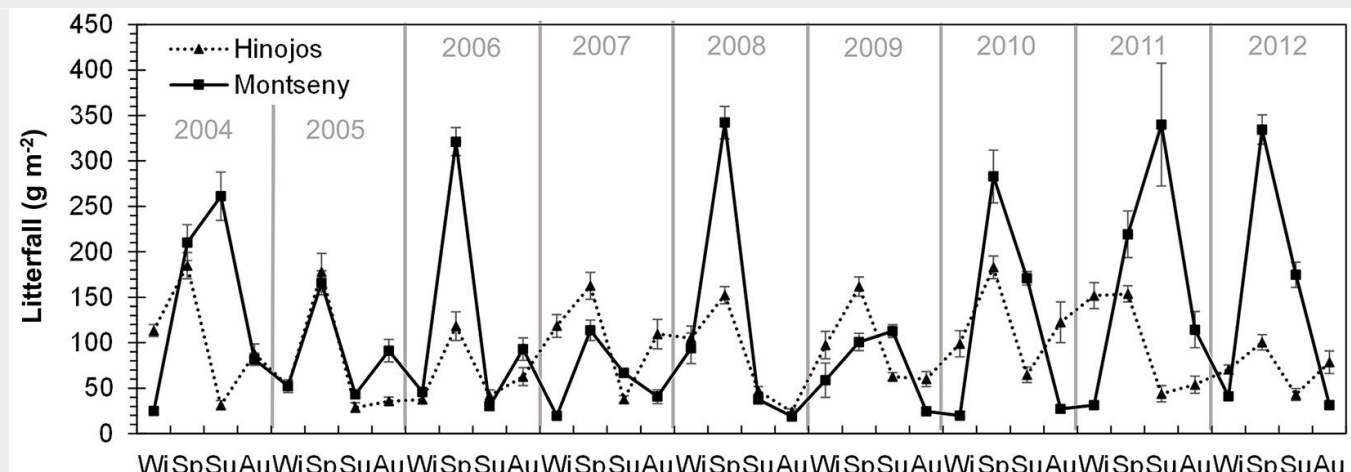

Fig. 2 - Seasonal pattern of litterfall (above) and leaf fall (below) for each study site over the study period. Error bars represent the standard error. Different years are separated by vertical lines. (Wi): winter; (Sp): spring; (Su): summer; (Au): autumn.

WiSpSuAuWiSpSuAuWiSpSuAuWiSpSuAuWiSpSuAuWiSpSuAuWiSpSuAuWiSpSuAuWiSpSuAu

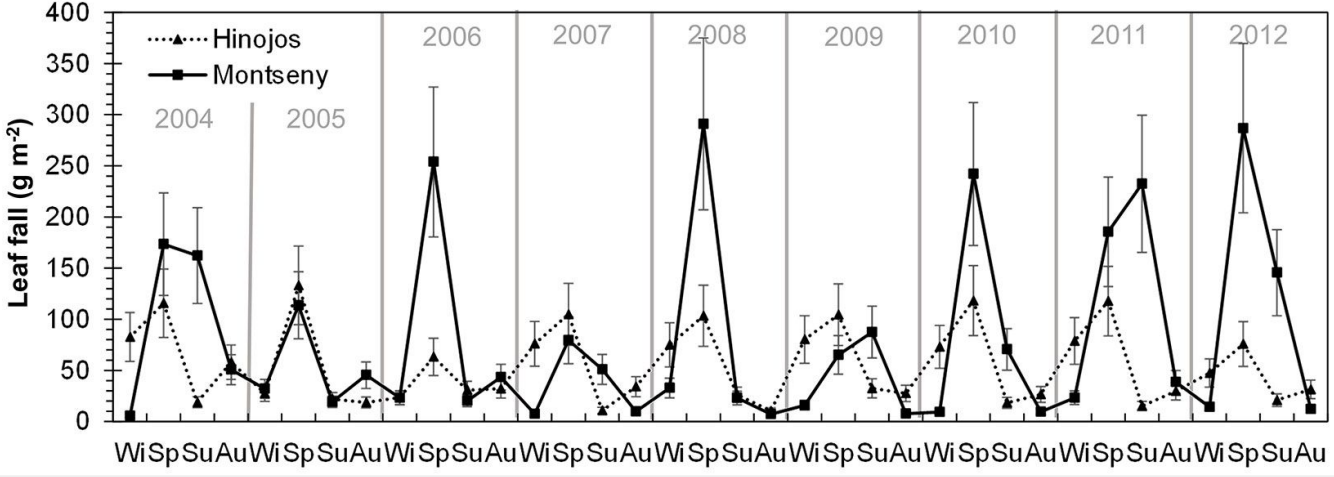

(Tab. S2 in Supplementary material). This means that a given observation within the same sampling point shows a temporary autocorrelation with the previous one. In all cases, the best supported model for the structure of the fixed effects included the triple interaction between site, year, and season or month (depending on the set of data). When models including the triple interaction were compared with models without this but considering pairwise interactions between fixed effects, the increase in AICC was greater than at least 100 units
(Tab. S3). In the selected models, VIF values were lower than 2 units indicating an acceptable degree of collinearity.

Leaf fall and litterfall showed a similar pattern both, at seasonal and monthly basis (Fig. 2, Fig. 3). Litterfall and leaf fall peaks mainly occurred in spring whereas the lowest values were found in winter, especially for leaf fall (Fig. 2). However, in some years in Montseny, litterfall and leaf fall showed a small peak in summer. Interestingly, a second litterfall and leaf fall peak occurred some years in autumn in both sites. The monthly analysis of litterfall data confirms these patterns. Litterfall peaks occurred earlier in Hinojos (between March and May) than in Montseny (between May and July - Fig. 3). The autumn peak was more frequent in Montseny than in Hinojos, and was mainly concentrated in October.

\section{Effect of climatic variables on litterfall} and leaf fall

The pairwise interactions between site and the climatic covariates (mT, P and

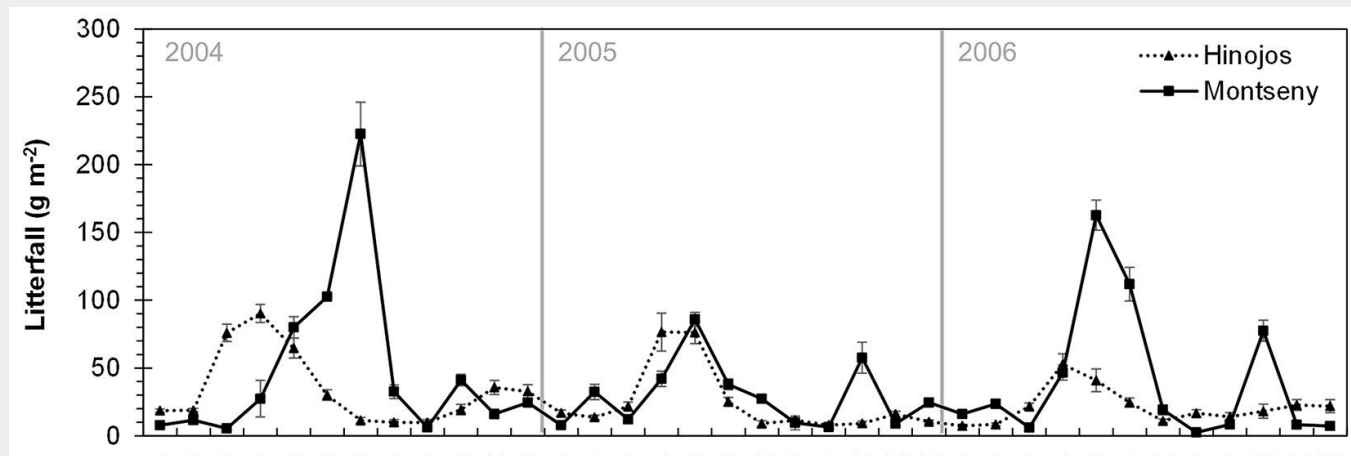

Fig. 3 - Monthly pattern of litterfall (above) and leaf fall (below) for each study site for the period 20042006. Error bars represent the standard error. Different years are separated by vertical lines. Months are numerically indicated in the horizontal axis.

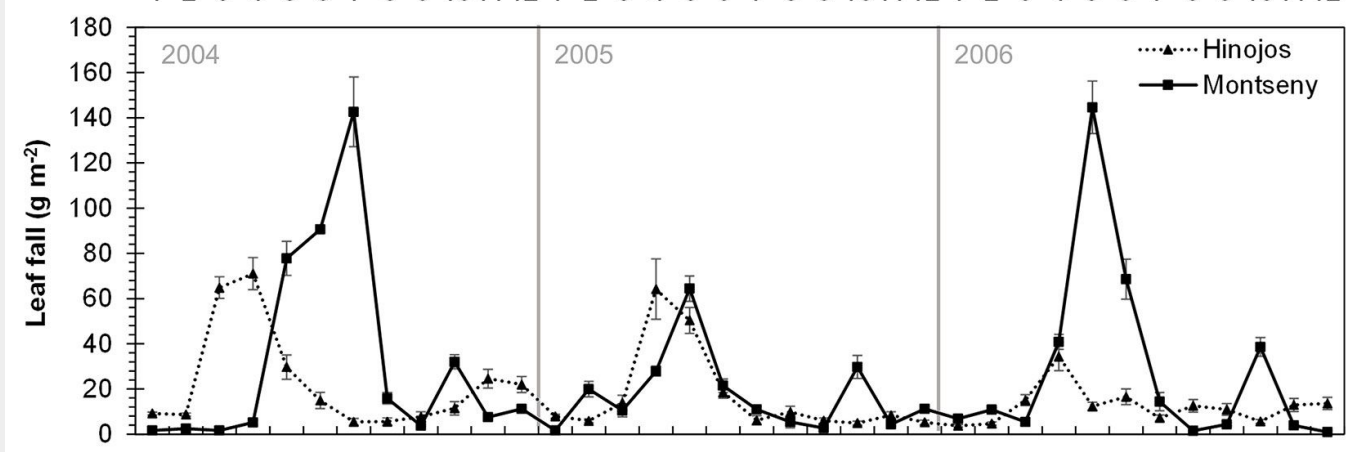

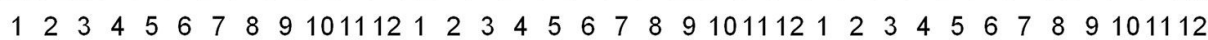


mWS) were included in the selected models for seasonal leaf fall and litterfall (Tab. 2, Tab. S4 in Supplementary material). The best supported model included the effect of precipitation as a quadratic term, and the effect of mean temperature and wind speed as linear terms (Tab. 2). Mean temperature and wind speed showed an opposite effect between sites (Fig. 4, Fig. S1). Seasonal leaf fall and litterfall increased linearly with mean temperature and wind speed in Montseny site, while remained constant or slightly decreased in Hinojos. Precipitation had a positive effect on seasonal leaf fall and litterfall production in $\mathrm{Hi}$ nojos site. In Montseny site, however, the greatest amount of leaf fall and litterfall occurred at the extremes of the precipitation values (Fig. 4). Interestingly, leaf fall during the second annual litterfall peak (i.e., autumn) was positively correlated with autumnal mean temperature $(r=0.26$, $p<0.001)$ but neither with precipitation or mean wind speed.

\section{Discussion}

Our results show similar patterns in the seasonality of litterfall and leaf fall between contrasting sites in terms of forest structure and climate. Once seasonality was removed, mean temperature, precipitation and mean wind speed were identified as the main determinants of litterfall and leaf fall. Interestingly, the effect of climatic variables differed between study sites, indicating an idiosyncratic forest response to climatic variability.

The amount of litterfall in our study (3.9 $\mathrm{Mg} \mathrm{ha}^{-1}$ year $^{-1}$ ) was similar to those values reported in other studies in Mediterranean cork oak (3.9-5.1 Mg ha-1 year-1 - Caritat et al. 1992, 1996, Rapp et al. 1999, Sá et al. 2005) and holm oak forests (3.8-6.9 $\mathrm{Mg} \mathrm{ha}^{-1}$ year $^{-1}$ - Bussotti et al. 2003, Andivia et al. 2013, Bou et al. 2015). Litterfall was greater in Montseny than in Hinojos as might be expected by the greater basal area and wetter climatic conditions in Montseny site (Berg \& Laskowski 2005, Roig et al. 2005).

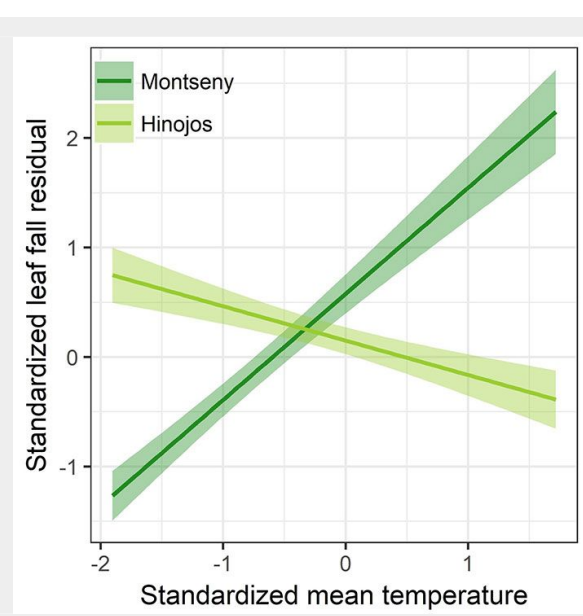

Tab. 2 - Mean values ( \pm SE) for each estimated parameter in the selected models for evaluating the effect of climate covariates on seasonal leaf fall and litterfall. For all models, "Hinojos" is the reference level for the site factor. (mT): mean temperature; (P): precipitation; (mWS): mean wind speed; $(*): p<0.05 ;(* *): p<0.01 ;(* * *): p<$ 0.001 .

\begin{tabular}{lll}
\hline Parameter & Leaf fall & Litterfall \\
\hline Intercept [“Hinojos”] & $0.12 \pm 0.04^{* *}$ & $0.13 \pm 0.04^{* *}$ \\
Site [“Montseny"] & $0.72 \pm 0.11^{* * *}$ & $0.62 \pm 0.11^{* * *}$ \\
$\mathrm{mT}$ & $-0.31 \pm 0.06^{* * *}$ & $-0.21 \pm 0.06^{* *}$ \\
$\mathrm{mT}^{2}$ & - & - \\
$\mathrm{P}$ & $1.55 \pm 1.38$ & $2.25 \pm 1.43$ \\
$\mathrm{P}^{2}$ & $-0.74 \pm 1.22$ & $-2.19 \pm 1.26$ \\
$\mathrm{mWS}$ & $-0.06 \pm 0.04$ & $-0.17 \pm 0.04^{* * *}$ \\
$\mathrm{mWS}$ & - & - \\
Site [“Montseny"] $\times \mathrm{mT}$ & $1.28 \pm 0.10^{* * *}$ & $1.03 \pm 0.10^{* * *}$ \\
Site [“Montseny"] $\times \mathrm{mT} T^{2}$ & - & - \\
Site [“Montseny"] $\times \mathrm{P}$ & $-4.79 \pm 2.25^{*}$ & $-6.82 \pm 2.34^{* *}$ \\
Site [“Montseny"] $\times \mathrm{P}^{2}$ & $8.46 \pm 2.10^{* * *}$ & $9.56 \pm 2.18^{* * *}$ \\
Site [“Montseny"] $\times \mathrm{mWS}$ & $0.26 \pm 0.09^{* *}$ & $0.32 \pm 0.09^{* * *}$ \\
Site [“Montseny”] $\times \mathrm{mWS}{ }^{2}$ & - & - \\
\hline
\end{tabular}

Other factors, such as stand age or soil nutrient richness might also explain differences between sites. Independently of the study site, litterfall showed a strong seasonal pattern with a major peak in spring (March-June). These results are consistent to those reported for Mediterranean evergreen oaks (Bellot et al. 1992, Rapp et al. 1999, Bussotti et al. 2003, Andivia et al. 2013, Bou et al. 2015). This seasonal pattern is tightly determined by leaf fall, which constitutes approximately $70 \%$ of the total litterfall amount. The main cause of leaf fall in spring is the renewal of the foliar cover after the bud flush (Escudero \& Del Arco 1987). Sá et al. (2005) reported that in average the leaf longevity of cork oak trees is 12 months, and the process of leaf shedding coincides in time with leaf emergence (Bellot et al. 1992, Bussotti et al. 2003). Leaf emergence in Mediterranean evergreen species tends to be concentrated in a single flush at the beginning of the grow- ing season (Mediavilla \& Escudero 2009). This process requires high temperatures and good water status to maintain cell turgor and construct new xylem tissue (Tognetti et al. 1998). Thus, Mediterranean evergreen trees could take advantage of the most physiologically favorable period of the year to renew their crown prior to the onset of the dry summer (Bussotti et al. 2003).

Whereas leaf fall peak always occurs in spring in Hinojos, we found high summer leaf fall values during some years in Montseny (years 2004, 2009, 2011 - Fig. 2). This might be related either to: (i) a delay in leaf fall because of low spring temperatures in Montseny. Mean minimum temperatures in May 2004 were $2.1{ }^{\circ} \mathrm{C}$ (average value of $8.2{ }^{\circ} \mathrm{C}$ for the study period); (ii) drought-induced xylem cavitation that can accelerate branch and leaf fall in summer (Ogaya \& Penuelas 2006, Misson et al. 2011). The summer of 2009 was especially
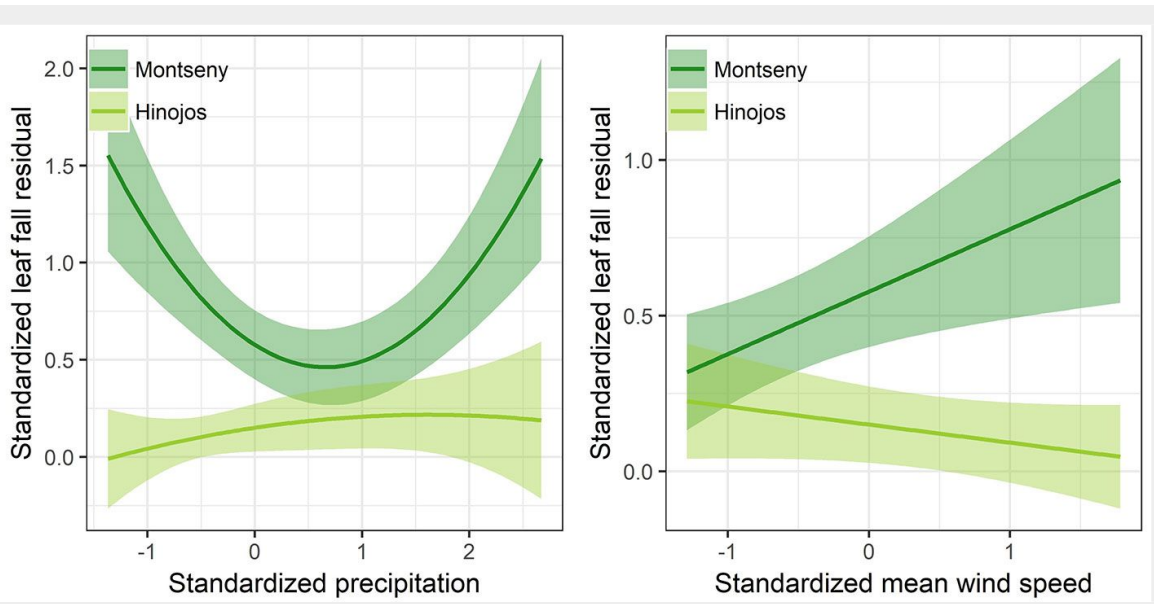

Fig. 4 - Model predictions and $95 \% \mathrm{Cl}$ for the effect of climatic covariates on seasonal leaf fall in the study sites (Montseny and Hinojos). Leaf fall for each covariate was predicted using a fixing mean value for the other two covariates. 
dry with mean maximum temperatures and precipitation of $27.6{ }^{\circ} \mathrm{C}$ and $42.9 \mathrm{~mm}$, respectively (average value of $25.9{ }^{\circ} \mathrm{C}$ and $180.6 \mathrm{~mm}$, respectively); or (iii) unusual summer storms, such as in 2011 with more than $200 \mathrm{~mm}$ of precipitation between June and July. When leaf fall was analyzed on a monthly basis, we observed that leaf fall peaks also show a delay between sites, occurring earlier in Hinojos than in Montseny (Fig. 3). This difference can be due to an earlier spring phenology in Hinojos as a consequence of the higher temperatures due to the contrasting latitude and altitude between both sites (Berg \& Laskowski 2005). In some years, leaf fall showed a second but much smaller peak in autumn, which has been also observed in other Mediterranean forests (Bussotti et al. 2003). This second peak may occur because of a second sprouting after summer drought supported by favorable environmental conditions (temperature, precipitation) in early autumn (Bussotti et al. 2003, Caritat et al. 2006). In fact, we found a positive correlation between autumnal leaf fall and autumnal temperatures. The strong seasonality of litterfall has important implications for other processes at ecosystem scale, such as soil respiration and nutrient cycling (Oliveira et al. 1996, DeForest et al. 2009, Andivia et al. 2015). In general, Mediterranean plants reduce nutrient losses through litterfall by the translocation of nutrients from senescent leaves to new leaves before leaf shedding (Escudero \& Del Arco 1987, Oliveira et al. 1996). As a consequence, litterfall shows higher $\mathrm{C}: \mathrm{N}$ ratios leading to lower decomposition rates (Sardans \& Peñuelas 2013). This strategy may enhance the ecosystem's capacity to retain nutrients in the upper part of the forest soil, ensuring nutrient availability to trees under favorable soil temperature and moisture (Oliveira et al. 1996, Sardans \& Peñuelas 2013).

After accounting for seasonality, our results identify mean temperature, precipitation and mean wind speed as the most important climatic factors affecting litterfall and leaf fall. Curiously, the direction of this effect was site-specific suggesting an idiosyncratic control of climatic conditions over litterfall. This differential effect might be mediated by endogenous factors, such as forest structure or age, but also by contrasting environmental severity between sites (Fig. 1). On the one hand, wind speed increased litterfall in Montseny while slightly affecting litterfall in Hinojos, in spite of the fact that wind and storms are expected to trigger leaf and twig shedding (Jonard et al. 2006). On the other hand, temperature has disparate effects on leaf fall in Montseny and Hinojos, respectively. In Montseny (northern Spain, $780 \mathrm{~m}$ a.s.l.), leaf fall increased with temperatures probably because of a higher leaf production and crown renewal. Overall, increasing temperatures have positive effects on forest productivity through the expansion of the growing period, enhancing meristem activity and photosynthesis (Körner 2015). However, increasing temperatures might also amplify drought severity in areas with water constraints (Lindner et al. 2010). In fact, the effect of temperature on leaf fall in Hinojos (southern Spain) was negative. Under water scarcity conditions, the production of new leaves may be reduced increasing leaf retention and longevity, which would consequently decrease litterfall (Hoff \& Rambal 2003, Misson et al. 2011). Nonetheless, drought conditions can also increase leaf fall because of xylem cavitation (Ogaya \& Penuelas 2006, Misson et al. 2011), by accumulating abscisic acid and ethylene hormones inducing senescence and abscission (Farooq et al. 2009, Zhang et al. 2014), or due to a general reduction in leaf area as a conservative strategy to reduce transpiration, maintain hydraulic conductance and avoid cavitation risk (Limousin et al. 2009, Barbeta et al. 2015). Liu et al. (2015) reported that litterfall was 10\% higher in plots with reduced water availability compared to control plots in a rainfall-exclusion experiment under similar environmental conditions than in Montseny. In line with these results, we found greater litterfall and leaf fall with lower precipitation in Montseny. In addition, the high forest density in Montseny might exacerbate summer drought leading to crown defoliation in order to adjust transpiration to water availability (Limousin et al. 2009). Contrastingly, litterfall and leaf fall were also greater with high precipitation, which might be related either to a greater leaf production during the spring or to a second litterfall peak in autumn (Caritat et al. 2006, Andivia et al. 2013). On the contrary, litterfall and leaf fall were not related to precipitation in Hinojos, where precipitation was lower than $600 \mathrm{~mm}$ in seven of the nine study years. Under these conditions, temperatures are expected to exert a greater control on litterfall than precipitation through modifying evapotranspiration (Berg \& Laskowski 2005). In this regard, Erkan et al. (2018) reported a non-significant relationship between litterfall and precipitation in pine forests but litterfall production increased significantly with aridity (as the ratio between temperature and precipitation).

Our results have practical implications for forest carbon cycle and productivity models. Most of these models use simplified algorithms to simulate litterfall process (Ito \& Oikawa 2002, Sitch et al. 2003), which might result in large uncertainties in soil respiration calculations (Zhang et al. 2014). Our results showed that litterfall seasonality differed between years and between sites, but more importantly the effect of climatic variables on litterfall was site-specific. Thus, incorporating this source of variability in these models seems appropriate to increase the accuracy of model predictions under climate change scenarios. In addition, further studies should explore the effect of different climate change scenarios on the patterns of litterfall production. In this regard, increasing our understanding of the influence of previous-year temperatures and precipitation on litterfall patterns is of pivotal importance to increase the accuracy of model predictions. This is especially important since there is some controversy as to whether resource limitation or year-to-year variation in climatic conditions drive certain aspects of forest productivity, such as masting (Kelly et al. 2013, Monks et al. 2016, Bisi et al. 2018).

\section{Conclusions}

Litterfall in Mediterranean cork oak forests shows a consistent seasonal pattern regardless of differences in forest structure. This pattern is mainly determined by leaf fall seasonality, which contributes to $70 \%$ of the total litterfall. Leaf fall is concentrated in spring, matching with the renewal of the foliar cover after the bud flush. In addition, a second but much smaller peak was observed some years in autumn. Differences in seasonality between sites were confined to an earlier leaf fall in spring in the study site located at lower latitude.

Mean temperature, precipitation and mean wind speed were the most important climatic factors affecting litterfall and leaf fall. Curiously, the effect of climatic variables differed between study sites indicating an idiosyncratic forest site response that might be mediated by differences in forest characteristics and environmental severity. Specifically, temperature increased leaf fall in the forest site located at a higher latitude and altitude, while leaf fall response to precipitation followed a positive quadratic relationship. Contrastingly, under water scarcity conditions leaf fall was reduced with increasing temperatures and did not respond to precipitation.

\section{Acknowledgments}

This study was supported by Ministry of Science and Innovation of Spain, the $\mathrm{Na}$ tional Agriculture Research Institute (INIA; ref: SUM2006-00026-00-00), and the Diputació de Girona, Spain. EA was supported by a postdoctoral grant founded by the Universidad Complutense in Madrid. We gratefully acknowledge the logistic support from the Montseny Natural Park, and the valuable help of numerous people during the sampling along the study period. We are also very grateful to Zoë Rohrer for the revision of the English language. The comments and suggestions of two anonymous reviewers contributed to improve previous version of this manuscript.

\section{Author Contributions}

All authors contributed to the study design and data collection. EA performed statistical analyses with inputs from JVP. EA wrote the manuscript with contributions from the rest of authors. 


\section{Conflicts of Interest}

The authors declare no conflict of interest.

\section{References}

Andivia E, Fernández M, Alejano R, VázquezPiqué J (2015). Tree patch distribution drives spatial heterogeneity of soil traits in cork oak woodlands. Annals of Forest Science 72: 549559. - doi: 10.1007/s13595-015-0475-8

Andivia E, Fernández M, Vázquez-Piqué J, González-Pérez A, Tapias R (2010). Nutrients return from leaves and litterfall in a mediterranean cork oak (Quercus suber L.) forest in southwestern Spain. European Journal of Forest Research 129: 5-12. - doi: 10.1007/s10342-009-0274-6

Andivia E, Vázquez-Piqué J, Fernández $M$, Ale jano R (2013). Litter production in Holm oak trees subjected to different pruning intensities in Mediterranean dehesas. Agroforestry Systems 87: 657-666. - doi: 10.1007/s10457-012-958 6-5

Barbeta A, Mejía-Chang M, Ogaya R, Voltas J, Dawson TE, Peñuelas J (2015). The combined effects of a long-term experimental drought and an extreme drought on the use of plantwater sources in a Mediterranean forest. Global Change Biology 21: 1213-1225. - doi: 10.1111/gcb. 12785

Bellot J, Sánchez JR, Lledó MJ, Martínez P, Escarré A (1992). Litterfall as a measure of primary production in Mediterranean holm-oak forest. In: "Quercus ilex L. Ecosystems: Function, Dynamics and Management" (Romane F, Terradas $\mathrm{J}$ eds). Advances in Vegetation Science, vol 13, Springer, Dordrecht, Netherlands, pp. 69-76. - doi: 10.1007/978-94-017-2836-2_6

Berg B, Laskowski R (2005). Litter fall. Advances in Ecological Research 38: 19-71. - doi: 10.1016/ S0065-2504(05)38002-0

Bisi F, Chirichella R, Chianucci F, Von Hardenberg J, Cutini A, Martinoli A, Apollonio M (2018). Climate, tree masting and spatial behaviour in wild boar (Sus scrofa L.): insight from a longterm study. Annals of Forest Science 75: 46. doi: 10.1007/s13595-018-0726-6

Bou J, Caritat A, Vilar L (2015). Litterfall and growth dynamics relationship with the meteorological variability in three forests in the Montseny natural park. Folia Forestalia Polonica 57: 145-159. - doi: 10.1515/ffp-2015-0015

Bussotti F, Borghini F, Celesti C, Leonzio C, Cozzi A, Bettini D, Ferretti M (2003). Leaf shedding, crown condition and element return in two mixed holm oak forests in Tuscany, central Italy. Forest Ecology and Management 176: 273285. - doi: 10.1016/S0378-1127(02)00283-9

Caritat A, Bertoni G, Molinas M, Oliva M, Dominguez-Planella A (1996). Litterfall and mineral return in two cork-oak forests in northeast Spain. Annales des Sciences Forestières 53: 1049-1058. - doi: 10.1051/forest:19960601

Caritat A, García-Berthou E, Lapeña R, Vilar L (2006). Litter production in a Quercus suber forest of Montseny (NE Spain) and its relationship to meteorological conditions. Annals of Forest Science 63: 791-800. - doi: 10.1051/forest:20060 61

Caritat A, Oliva Estanyol M, De Ferrer M (1992). Variación estacional del desfronde en dos parcelas de alcornocal [Litterfall seasonality in two
Cork oak sites]. Scientia Gerundensis 18: 121. [in Spanish]

Chen HY, Brant AN, Seedre M, Brassard BW, Taylor AR (2017). The contribution of litterfall to net primary production during secondary succession in the boreal forest. Ecosystems 20: 830-844. - doi: 10.1007/s10021-016-0063-2

Christensen JH, Christensen OB (2007). A summary of the PRUDENCE model projections of changes in European climate by the end of this century. Climatic Change 81: 7-30. - doi: 10.1007/ s10584-006-9210-7

DeForest JL, Chen J, McNulty SG (2009). Leaf litter is an important mediator of soil respiration in an oak-dominated forest. International Journal of Biometeorology 53: 127-134. - doi: 10.100 7/s00484-008-0195-y

Erkan N, Comez A, Aydin AC, Denli O, Erkan S (2018). Litterfall in relation to stand parameters and climatic factors in Pinus brutia forests in Turkey. Scandinavian Journal of Forest Research 33: 338-346. - doi: 10.1080/02827581.20 17.1406135

Escudero A, Del Arco JM (1987). Ecological significance of the phenology of leaf abscission. Oikos 49: 11-14. - doi: 10.2307/3565549

Estiarte M, Peñuelas J (2014). Alteration of the phenology of leaf senescence and fall in winter deciduous species by climate change: effects on nutrient proficiency. Global Change Biology 21: 1005-1017. - doi: 10.1111/gcb.12804

Falge E, Baldocchi D, Tenhunen J, Aubinet M, Bakwin $P$, Berbigier $P$, Bernhofer $C$, Burba $G$, Clement R, Davis KJ, Elbers JA, Goldstein $A H$, Grelle A, Granier A, Gumundsson J, Hollinger D, Kowalski AS, Katul G, Law BE, Malhi Y, Meyers T, Monson RK, Munger JW, Oechel W, Paw UKT, Pilegaard K, Rannik U, Rebmann C, Suyker A, Valentini R, Wilson K, Wofsy S (2002). Seasonality of ecosystem respiration and gross primary production as derived from FLUXNET measurements. Agricultural and Forest Meteorology 113: 53-74. - doi: 10.1016/So168-1923(02) 00102-8

Farooq M, Wahid A, Kobayashi N, Fujita D, Basra SMA (2009). Plant drought stress: effects, mechanisms and management. Agronomy for Sustainable Development 29: 185-202. - doi: 10.1051/agro:2008021

Giorgi F (2006). Climate change hot-spots. Geophysical Research Letters 33 (8): 89. - doi: 10.1029/2006GL025734

Han T, Huang W, Liu J, Zhou G, Xiao Y (2015). Different soil respiration responses to litter manipulation in three subtropical successional forests. Scientific Reports 5 (1): 81. - doi: 10.1038/ srep18166

Hobbie SE (2015). Plant species effects on nutrient cycling: revisiting litter feedbacks. Trends in Ecology and Evolution 30: 357-363. - doi: 10.1016/j.tree.2015.03.015

Hoff C, Rambal S (2003). An examination of the interaction between climate, soil and leaf area index in a Quercus ilex ecosystem. Annals of Forest Science 60: 153-161. - doi: 10.1051/forest: 2003008

Ito A, Oikawa T (2002). A simulation model of the carbon cycle in land ecosystems (Sim-CYCLE): a description based on dry-matter production theory and plot-scale validation. Ecological Modelling 151: 143-176. - doi: 10.1016/So3
04-3800(01)00473-2

IUSS/WRB (2007). World reference base for soil resources 2006, first update 2007. FAO, Rome, Italy, pp. 116.

Jonard M, Andre F, Ponette Q (2006). Modeling leaf dispersal in mixed hardwood forests using a ballistic approach. Ecology 87: 2306-2318. doi: 10.1890/0012-9658(2006)87[2306:MLDIM $\mathrm{H}] 2.0 . \mathrm{CO}$;

Kelly D, Geldenhuis A, James A, Penelope Holland E, Plank MJ, Brockie RE, Cowan PE, Harper GA, Lee WG, Maitland MJ, Mark AF, Mills JA, Wilson PR, Byrom AE (2013). Of mast and mean: differential-temperature cue makes mast seeding insensitive to climate change. Ecology Letters 16: 90-98. - doi: 10.1111/ele.12020 Körner C (2015). Paradigm shift in plant growth control. Current Opinion in Plant Biology 25: 107-114. - doi: 10.1016/j.pbi.2015.05.003 Limousin JM, Rambal S, Ourcival JM, Rocheteau A, Joffre R, Rodríguez-Cortina R (2009). Longterm transpiration change with rainfall decline in a Mediterranean Quercus ilex forest. Global Change Biology 15: 2163-2175. - doi: 10.1111/j.136 5-2486.2009.01852.x

Lindner M, Maroschek M, Netherer S, Kremer A, Barbati A, Garcia-Gonzalo J, Seidl R, Delzon S, Corona P, Kolström M, Lexer MJ, Marchetti M (2010). Climate change impacts, adaptive capacity, and vulnerability of European forest ecosystems. Forest Ecology and Management 259: 698-709. - doi: 10.1016/j.foreco.2009.09.0 23

Liski J, Palosuo T, Peltoniemi M, Sievänen R (2005). Carbon and decomposition model Yasso for forest soils. Ecological Modelling 189: 168-182. - doi: 10.1016/j.ecolmodel.2005.03.005 Liu D, Ogaya R, Barbeta A, Yang X, Peñuelas J (2015). Contrasting impacts of continuous moderate drought and episodic severe droughts on the aboveground-biomass increment and litterfall of three coexisting Mediterranean woody species. Global Change Biology 21: 4196-4209. doi: 10.1111/gcb.13029

Mediavilla S, Escudero A (2009). Ontogenetic changes in leaf phenology of two co-occurring Mediterranean oaks differing in leaf life span. Ecological Research 24 (5): 1083-1090. - doi: 10.1007/s11284-009-0587-4

Metcalfe D, Liddell M, Bradford MG, Green PT (2014). Tropical rainforests of eastern Australia. In: "Biodiversity and Environmental Change: Monitoring, Challenges and Direction" (Lindenmayer D, Burns E, Thurgate N, Lowe A). CSIRO Publishing, Collingwood, Australia pp. 111-165. [online] URL: http://books.google.com/books? id=XXjAAgAAQBAJ

Misson L, Degueldre D, Collin C, Rodriguez R, Rocheteau A, Ourcival J, Rambal S (2011). Phenological responses to extreme droughts in a Mediterranean forest. Global Change Biology 17: 1036-1048. - doi: 10.1111/j.1365-2486.2010.023 48.x

Monks A, Monks JM, Tanentzap AJ (2016). Resource limitation underlying multiple masting models makes mast seeding sensitive to future climate change. New Phytologist 210: 419-430. doi: 10.1111/nph.13817

Ogaya R, Penuelas J (2006). Contrasting foliar responses to drought in Quercus ilex and Phillyrea latifolia. Biologia Plantarum 50: 373-382. 
doi: 10.1007/s10535-006-0052-y

Oliveira G, Martins-Loução MA, Correia O, Catarino $F$ (1996). Nutrient dynamics in crown tissues of cork-oak (Quercus suber L.). Trees 10: 247-254. - doi: 10.1007/BF02185676

Pausas JG (1997). Litter fall and litter decomposition in Pinus sylvestris forests of the eastern Pyrenees. Journal of Vegetation Science 8: 643650. - doi: $10.2307 / 3237368$

Pedersen LB, Bille-Hansen J (1999). A comparison of litterfall and element fluxes in even aged Norway spruce, sitka spruce and beech stands in Denmark. Forest Ecology and Management 114: 55-70. - doi: 10.1016/S0378-1127(98)00381-8 Pinheiro J, Bates D, DebRoy S, Sarkar D, R Core Team (2017). nlme: linear and nonlinear mixed effects models. R package version 3: 1-131. [online] URL: http://CRAN.R-project.org/package= nlme

Rapp M, Santa Regina I, Rico M, Gallego HA (1999). Biomass, nutrient content, litterfall and nutrient return to the soil in Mediterranean oak forests. Forest Ecology and Management 119: 39-49. - doi: 10.1016/S0378-1127(98)00508-8 Roig S, Del Río M, Cañellas I, Montero G (2005). Litter fall in Mediterranean Pinus pinaster Ait. stands under different thinning regimes. Forest Ecology and Management 206: 179-190. - doi: 10.1016/j.foreco.2004.10.068
Sá C, Madeira M, Gazarini L (2005). Produção e decomposição de folhas da folhada de Quercus suber L. e Q. rotundifolia Lam. [Leaf litter and decomposition in Quercus suber $L$ and Q. rotundifolia Lam.]. Revista de Ciências Agrárias 28: 257-272. [in Portuguese]

Sardans J, Peñuelas J (2013). Plant-soil interactions in Mediterranean forest and shrublands: impacts of climatic change. Plant and Soil 365: 1-33. - doi: 10.1007/s11104-013-1591-6

Sayer EJ (2005). Using experimental manipulation to assess the roles of leaf litter in the functioning of forest ecosystems. Biological Reviews 81: 1-31. - doi: 10.1017/S1464793105006846 Sitch S, Smith B, Prentice IC, Arneth A, Bondeau A, Cramer W, Kaplan JO, Levis S, Lucht W, Sykes MT, Thonicke K, Venevsky S (2003). Evaluation of ecosystem dynamics, plant geography and terrestrial carbon cycling in the LPJ dynamic global vegetation model. Global Change Biology 9: 161-185. - doi: 10.1046/j.1365-2486.20 03.00569.x

Tognetti R, Longobucco A, Raschi A (1998). Vulnerability of xylem to embolism in relation to plant hydraulic resistance in Quercus pubescens and Quercus ilex co-occurring in a Mediterranean coppice stand in central Italy. New Phytologist 139: 437-447. - doi: 10.1046/j.1469-8137.19 98.00207.x
Zhang H, Yuan W, Dong W, Liu S (2014). Seasonal patterns of litterfall in forest ecosystem world wide. Ecological Complexity 20: 240-247. - doi: 10.1016/j.ecocom.2014.01.003

Zuur AF, leno EN, Walker N, Saveliev AA, Smith GM (2009). Mixed effects models and extensions in ecology with R. Springer-Verlag, New York, USA, pp. 574.

\section{Supplementary Material}

Tab. S1 - Correlation among climatic variables.

Tab. S2 - Model comparison between autoregressive random structures.

Tab. S3 - Model comparison for fixed effect.

Tab. S4 - Value of parameters for the model used to assess climate effect on leaf fall and litterfall.

Fig. S1 - Climatic variables effect on litterfall.

Link: Andivia_2825@supplo01.pdf 